\title{
Deslocamento do tendão flexor digital superficial da tuberosidade do calcâneo
}

Pollyanna Stremel Romeiro ${ }^{[]]}$, Luis Fernando Coelho Bastos ${ }^{[b]}$

[a] Universidade Tuiuti do Paraná (UTP), Curitiba, PR, Brasil

[b] Universidade Federal do Rio Grande do Sul (UFRGS), Porto Alegre, RS, Brasil

*Autor correspondente

e-mail: pollyanna_str@hotmail.com

\section{Resumo}

O deslocamento do tendão flexor digital superficial (SDFT) é causado pela ruptura de uma das fáscias de inserção, cuja função é fixar o tendão na tuberosidade do calcâneo para que esse não se desloque (medialmente ou lateralmente) no momento da flexão do membro. Uma vez rompida, ocorre a contração da fáscia oposta, ocasionando o deslocamento do tendão. Tal ruptura geralmente é consequência de um trauma de alta intensidade, que pode estar associado ou não à fratura. 0 objetivo desse relato é descrever a ocorrência da patologia e a importância da ultrassonografia no diagnóstico definitivo. Um equino, Brasileiro de Hipismo, fêmea, 6 anos, com histórico de surgimento de edema acentuado, durante o esforço físico, em aspecto plantar da articulação társica esquerda, foi atendido a campo por um médico veterinário. No exame radiográfico não foram constatadas alterações significativas. No exame ultrassonográfico, observou-se presença de área anecóica difusa em aspecto plantar de região társica, espessamento de tecido subcutâneo, diminuição de ecogenicidade difusa e espessamento do SDFT, presença de fluído anecóico com celularidade na bursa do gastrocnêmico e do calcâneo. Devido à dificuldade presente no exame, causada pelo grande acúmulo de líquido, optou-se pela reavaliação ultrassonográfica em 15 dias. Coletou-se o líquido sinovial das bursas para análise laboratorial, a qual confirmou a presença de células inflamatórias. A fim de reduzir o edema instalado, foi realizada infiltração das bursas com acetonido de triancinolona $(0,01 \mathrm{~mL} / \mathrm{kg}) \mathrm{em}$ dose única. Posterior ao intervalo de tempo necessário, realizou-se o segundo exame ultrassonográfico, que confirmou a alteração de topografia do SDFT, o qual se apresentava lateralizado em relação ao tendão gastrocnêmico e ao ligamento plantar longo. Uma vez diagnosticado o deslocamento, o proprietário preferiu encerrar a vida atlética do animal e não optar pelo tratamento cirúrgico devido à baixa taxa de sucesso. 0 diagnóstico torna-se mais claro quando há diminuição do edema associado aos exames complementares, 
corroborando com o caso relatado. Atualmente, o tratamento cirúrgico apresenta alta taxa de recidiva, o que não garante o retorno da atividade atlética do paciente. Embora a patologia da região társica seja uma das maiores causas de claudicação de membro pélvico, o deslocamento do SDFT é incomum na rotina veterinária. No entanto, quando ocorre, o deslocamento lateral é o mais frequente. 0 custo do tratamento cirúrgico torna-se inviável, devido à baixa taxa de sucesso. Os exames complementares mostram-se de extrema importância nesse caso para confirmação diagnóstica, em especial a ultrassonografia, pois esta permite, de forma não invasiva, a visualização e a avaliação das estruturas moles presentes.

Palavras-chave: Luxação. Deslocamento. SDFT. 